\title{
Effects of fumarate on ruminal ammonia accumulation and fiber digestion in vitro and nutrient utilization in dairy does ${ }^{1}$
}

\author{
C.-W. Yu, ${ }^{*}$ Y.-S. Chen, ${ }^{*}$ Y.-H. Cheng, ${ }^{*}$ Y.-S. Cheng, ${ }^{, 2}$ C.-M. J. Yang, ${ }^{* 3}$ and C.-T. Chang† \\ ${ }^{*}$ Department of Animal Science, National I-Lan University, I-Lan, Taiwan 260, Republic of China \\ †Tai-Tung Animal Propagation Station, Livestock Research Institute, Tai-Tung, Taiwan 954, Republic of China
}

\begin{abstract}
The objective of this study was to evaluate effects of fumarate on ruminal ammonia accumulation and fiber digestion in vitro and on feed intake and nutrient utilization in dairy does. Batch cultures of mixed rumen microorganisms were used to study effects of different concentrations of fumarate on fermentation with various $\mathrm{N}$ sources (ammonia as ammonium bicarbonate, casein amino acids, casein peptides, gelatin peptides) and feeds (bermudagrass hay, mixed diet of $60 \%$ bermudagrass hay plus $40 \%$ concentrate) for 6 and $24 \mathrm{~h}$, respectively. Substrates were grouped into pairs for separate incubations. Monosodium fumarate was added to incubation tubes to achieve final concentrations of 0 , 5, and $10 \mathrm{~m} M$ fumarate. More ammonia accumulated at the end of incubation with added ammonium bicarbonate. Ammonia concentration was higher for peptide compared with amino acid incubation, and for casein peptide compared with gelatin peptide. Addition of fumarate linearly decreased ammonia for all $\mathrm{N}$ sources and for feed substrates. For all substrate types, fumarate treatment increased acetate, propionate, and total volatile fatty acids (VFA), decreased acetate to propionate ratio, and tended to reduce branched-chain VFA. Digestion of feed neutral detergent fiber (NDF) by rumen microorganisms was improved by fumarate along with elevated endoglucanase and xylanase activities. In an animal metabolism experiment, 8 dairy does (4 per treatment) were used in a completely randomized design for $21 \mathrm{~d}$. Does were fed a hay plus concentrate diet without (control) or with fumarate $(6 \mathrm{~g} / \mathrm{head}$ per day) supplementation to determine feed intake, whole-tract nutrient digestibility, and $\mathrm{N}$ utilization. Fumarate treatment did not affect weight change or feed intake but increased whole-tract digestion of gross
\end{abstract}

Received June 16, 2009

Accepted September 20, 2009.

${ }^{1}$ This research project (NSC 93-2313-B-197-006) was supported by

National Science Council, Taiwan, Republic of China.

${ }^{2}$ Present address: National Animal Industry Foundation, Tai-Pei, Taiwan 106, Republic of China.

${ }^{3}$ Corresponding author: cmyang@niu.edu.tw energy, crude protein, and cellulose. Digested N was increased by fumarate supplementation; however, N retention was unaffected. Plasma glucose concentration was elevated with fumarate but urea $\mathrm{N}$ concentration remained unchanged. Fumarate addition had significant effects on rumen microbial fermentation by decreasing ammonia and branched-chain VFA, and by increasing acetate and propionate, and NDF digestion. These effects were reflected in the improvement in whole-tract gross energy, crude protein, and cellulose digestion and elevated plasma glucose concentration when dairy does were supplemented with fumarate.

Key words: fumarate, rumen, ammonia, fiber digestion

\section{INTRODUCTION}

Fumarate is a key intermediate in rumen microbial metabolism. Fumarate is reduced to succinate, which is then decarboxylated to propionate (Asanuma et al., 1999; López et al., 1999). During this process, hydrogen is consumed with the production of carbon dioxide. When hydrogen is used to reduce fumarate, less is available for methanogenesis. By an alternative pathway, fumarate is metabolized to acetate, but to a much smaller extent than it is converted to propionate (Demeyer and Henderickx, 1967). Thus, ruminal fermentation of fumarate could increase both acetate and propionate, although a decrease in acetate to propionate ratio often results (Asanuma et al., 1999; Carro and Ranilla, 2003).

Methane is an energy-rich compound but is unavailable to the microorganisms and the host animal before dissipation to the atmosphere, contributing to greenhouse gas. The reduction in methane by fumarate addition has been shown to increase available energy per unit of fermentable substrate in the rumen (Carro and Ranilla, 2003). Propionate is converted to glucose after absorption and is thus an important glucogenic precursor for ruminants (Wiltrout and Satter, 1972). Glucogenic amino acids are also precursors for glucose. Therefore, increasing propionate by fumarate could potentially spare glucogenic amino acids. 
Asanuma et al. (1999) reported that ATP produced from fumarate metabolism could be used by rumen microorganisms for growth. In addition, Linehan et al. (1978) indicated that fumarate could serve as a carbon precursor for amino acid synthesis by incorporation of ammonia. It appears that fumarate could provide energy and carbon skeletons for ammonia utilization by ruminal microorganisms. Cellulolytic rumen bacteria have a requirement for ammonia (Bryant, 1973) and thus may benefit from fumarate supplementation. Previous studies showed that fiber-degrading rumen bacteria are enhanced by additional fumarate (Isobe and Shibata, 1993; Asanuma et al., 1999; López et al., 1999) and therefore may lead to improved fiber digestion in animals.

Fumarate has been reported to decrease ruminal ammonia (Stallcup and Barr, 1983; Isobe and Shibata, 1993; Bayaru et al., 2001). Whether this reduction is a result of an increase in ammonia utilization or a decrease in peptides and amino acids deamination is not clear. Peptides and amino acids are intermediates in ruminal protein degradation (Chen et al., 1987a). When the supply of ruminally degradable carbohydrate is limited, much of the peptides and amino acids can be deaminated and ammonia will accumulate. Reducing ruminal ammonia could minimize energy cost for converting excess ammonia absorbed into urea.

Diets containing large amounts of forage generally lead to a high-methane, low-propionate type of ruminal fermentation, which incurs an inefficiency of energy utilization by ruminants (Van Soest, 1982). In addition, when animals are fed large amounts of low quality forage and concentrate with a high RDP content, there is often an imbalance between ruminal protein (high CP degradability) and carbohydrate fermentation (low carbohydrate availability), and excess ammonia can accumulate in the rumen (Nocek and Russell, 1988).

Many studies have presented favorable effects of fumarate on ruminal fermentation. However, little research has been conducted to associate these effects with animal performance. Based on potential actions by fumarate to reduce methane and ammonia and to increase propionate and fiber digestion in the rumen, ruminant animals should respond to fumarate supplementation when diets contain large amounts of low quality forage plus small amounts of $\mathrm{CP}$ as true protein with high solubility. Replacement dairy does in Taiwan are generally fed low quality forage with restricted concentrate. Such a dietary condition may limit nutrient availability for animals, because of low fiber digestibility and poor $\mathrm{N}$ utilization. Our objective was to evaluate effects of fumarate on ruminal ammonia accumulation and fiber digestion in vitro and intake and whole-tract nutrient digestibility in dairy goats.
Table 1. Chemical composition of bermudagrass hay and concentrate fed to dairy goats

\begin{tabular}{lcc}
\hline Item & Hay & Concentrate $^{1}$ \\
\hline DM, \% & 91.7 & 89.5 \\
Gross energy, Mcal/kg of DM & 4.32 & 4.38 \\
OM, \% of DM & 92.1 & 93.3 \\
CP, \% of DM & 4.62 & 19.1 \\
Soluble CP, \% of CP & 72.7 & 75.1 \\
Ether extract, \% of DM & 1.02 & 3.09 \\
NDF, \% of DM & 70.1 & 29.0 \\
ADF, \% of DM & 32.5 & 8.22 \\
Cellulose, \% of DM & 24.4 & 6.34 \\
Acid detergent lignin, \% of DM & 6.47 & 2.48 \\
Hemicellulose, \% of DM & 37.5 & 20.7 \\
NFC, \% of DM & 16.5 & 42.1 \\
\hline
\end{tabular}

${ }^{1}$ Contained $52.0 \%$ ground corn, $17.3 \%$ soybean meal, $10.4 \%$ wheat bran, $17.3 \%$ alfalfa meal, $1.73 \%$ limestone, $0.87 \%$ dicalcium phosphate, $0.35 \%$ trace mineral salt, on a fresh basis.

${ }^{2} \mathrm{OM}-\mathrm{CP}-$ ether extract - NDF.

\section{MATERIALS AND METHODS}

\section{In Vitro Experiment}

Two ruminally fistulated crossbred (Alpine $\times$ Nubian $\times$ Saanen) wether dairy goats (approximately $55 \mathrm{~kg}$ each) were used as rumen fluid donors. The wethers were housed in individual box pens and given a high forage and low concentrate diet consisting of bermudagrass hay ad libitum and $0.115 \mathrm{~kg}(\mathrm{DM})$ of a commercial farm concentrate (Table 1) fed twice daily (0800 and $1800 \mathrm{~h}$ ). Mineral salt block and water were provided for free access. The composition of the mineral salt block was as follows (\% of DM): $\mathrm{Na}$ (38.4), $\mathrm{Mg}$ (1.5), $\mathrm{Zn}$ (0.25), Mn (0.075), Se (0.0015), Fe (0.15), Cu (0.035), I (0.0038), and Co (0.0015). Animal procedures and protocols were approved by the National I-Lan University Institutional Animal Care and Use Committee (I-Lan, Taiwan, Republic of China).

Immediately before the morning feeding, rumen contents were collected and combined from the wethers via rumen cannula and squeezed through 4 layers of cheesecloth into a glass flask. This rumen fluid was strained again through 8 layers of cheesecloth to further remove small feed particles. Presumably, microorganisms obtained in the rumen fluid represented mostly fluid-associated populations.

The one-stage in vitro rumen fermentation conditions were similar to those described by Goering and Van Soest (1970). Triplicate polyethylene centrifuge tubes $(50 \mathrm{~mL})$ were used for incubation (anaerobic, $39^{\circ} \mathrm{C}$ ) containing $5 \mathrm{~mL}$ of artificial saliva (McDougall, 1948), $5 \mathrm{~mL}$ of strained rumen fluid, and specific substrates, which were ammonium bicarbonate $\left(\mathrm{NH}_{4} \mathrm{HCO}_{3}, 2.3\right.$ $\mathrm{g} / \mathrm{L}$ ), casein amino acid (5 g/L, Casein, Acid Hydrolysate, Sigma, St. Louis, MO), casein peptide (5 g/L, 
N-Z-Case Plus, Sigma), gelatin peptide ( $5 \mathrm{~g} / \mathrm{L}$, Gelatin Hydrolysate Enzymatic, Sigma), bermudagrass hay (10 $\mathrm{g} / \mathrm{L})$, and mixed diet ( $60 \%$ bermudagrass hay $+40 \%$ concentrate, $10 \mathrm{~g} / \mathrm{L})$.

Before inoculation of rumen fluid, substrates were presoaked with artificial saliva solution and prewarmed in a water bath at $39^{\circ} \mathrm{C}$ for $30 \mathrm{~min}$. Rumen fluid was saturated with $\mathrm{CO}_{2}$ and maintained at $39^{\circ} \mathrm{C}$ during inoculation of fermentation tubes. After inoculation of rumen fluid, the gas phase (open space) of the fermentation tubes was gassed with $\mathrm{CO}_{2}$ for $5 \mathrm{~s}$; then the tubes were sealed with a rubber stopper equipped with a Bunsen valve. Tubes were incubated in a water bath at $39^{\circ} \mathrm{C}$ with occasional swirling of the contents by hand. The incubation time for $\mathrm{N}$ and feed substrates was 6 and $24 \mathrm{~h}$, respectively.

Treatments included the addition of 0,5 , and 10 $\mathrm{m} M$ fumarate to incubation tubes for each substrate. Monosodium fumarate (Nippon Shokubei Co. Ltd., Osaka, Japan) was used to achieve the respective final concentrations of fumarate. Substrates were grouped into pairs for separate incubations as follows: without or with $\mathrm{NH}_{4} \mathrm{HCO}_{3}$, casein amino acids versus casein peptides, casein peptides versus gelatin peptides, and bermudagrass hay versus mixed diet. Fumarate was added to each substrate pair for factorial comparison. Tubes containing no substrates and treatment additives served as control blanks. For incubations with feed substrates, $\mathrm{NH}_{4} \mathrm{HCO}_{3}(2.3 \mathrm{~g} / \mathrm{L})$ was also included to ensure there was enough ammonia for microbial degradation. All incubations were conducted in triplicate runs.

At the end of the incubation, supernatants were obtained by centrifugation $\left(13,000 \times g, 4^{\circ} \mathrm{C}, 15 \mathrm{~min}\right)$ and measured for $\mathrm{pH}$ using a glass electrode. Aliquot supernatants were stored $\left(4^{\circ} \mathrm{C}\right)$ until determination for fibrolytic activities within $24 \mathrm{~h}$. Endoglucanase and xylanase activities in supernatants were assayed by using carboxymethyl cellulose (Sigma) and oat spelt xylan (Sigma) as substrates, respectively. Except for the $\mathrm{pH}$ at which determinations were performed (6.8), assays were carried out using the procedures similar to those described by Morgavi et al. (2000). Supernatant samples of $0.5 \mathrm{~mL}$ were added to test tubes (duplicates) containing $1 \mathrm{~mL}$ of $2 \%$ of the respective activity substrates in $20 \mathrm{~m} M$ citrate buffer ( $\mathrm{pH} \mathrm{6.8).} \mathrm{The} \mathrm{mixtures}$ were incubated at $39^{\circ} \mathrm{C}$ for $3 \mathrm{~h}$, and the reaction was stopped on ice and centrifuged $\left(13,000 \times g, 4^{\circ} \mathrm{C}, 15\right.$ min). The supernatants were analyzed for reducing sugars produced with glucose or xylose as a standard, by the dinitrosalicylic acid method (Miller, 1959).

Subsamples of fermentation supernatant were acidified by adding (1\%) $50 \%$ sulfuric acid and frozen for later analysis of ammonia and VFA. Ammonia was measured by the colorimetric method of Chaney and
Marbach (1962). Ruminal VFA were determined using GLC with a column $2 \mathrm{~m}$ long $\times 2 \mathrm{~mm}$ i.d. packed with Carbowax $20 \mathrm{M}$ on 80/100 Carbopack B-PA (Supelco Inc., Bellefonte, PA), as described by Yang and Varga (1989).

For NDF measurement (Van Soest et al., 1991), the whole contents in fermentation tubes were decanted into $600-\mathrm{mL}$ Berzelius beakers. Tubes were then washed with several portions of NDF solution to transfer all the remaining residues from the tubes. Digestibility was calculated as the amount of NDF that disappeared during the incubation relative to the initial amount. The values were corrected for those obtained from control blanks. Analysis of NDF on blank incubations (without substrate) at the beginning and at the end showed no detectable NDF, indicating no ruminal feed particle contamination.

\section{Animal Intake, Whole-Tract Digestion, and Nitrogen Balance Experiment}

Eight crossbred dairy does $(35.8 \mathrm{~kg}, \mathrm{SE}=1.2 \mathrm{~kg})$ were assigned randomly to 1 of 2 dietary treatments, without (control) or with fumarate ( $6 \mathrm{~g} /$ head per day) supplementation. Feeding fumarate at $>6 \mathrm{~g}$ per head daily caused erratic feed intake by goats in a preliminary trial. The does were housed in individual stainless steel crates for determination of feed intake and separation of urine and feces (Yang et al., 2003).

Does were fed chopped bermudagrass hay ad libitum (10\% weighbacks) and a commercial concentrate at a regulated level $(0.235 \mathrm{~kg}$ of DM per head per d). The feeding regimen was estimated to marginally exceed maintenance requirements for $\mathrm{ME}$ and $\mathrm{CP}$ (NRC, 1981). Fumarate was added by mixing with the concentrate before each feeding. Both feeds were provided to goats twice daily (0800 and $1800 \mathrm{~h}$ ), and water and mineral salt block were available for ad libitum access. Chemical composition of hay and concentrate fed is shown in Table 1.

The experiment lasted for $21 \mathrm{~d}$, with $14 \mathrm{~d}$ for animal adaptation to experimental diets and $7 \mathrm{~d}$ for sample collection. Hay and concentrate were fed separately, and concentrate was always consumed completely within 10 min after each feeding. Hay, concentrate, and orts samples and total feces and urine were collected daily and pooled over the 7-d period. Daily feces collected were refrigerated $\left(4^{\circ} \mathrm{C}\right)$ for later analysis. At the termination of collection period, feed, orts, and fecal samples were dried at $55^{\circ} \mathrm{C}(72 \mathrm{~h})$ in a forced-air oven and weighed.

Dried samples were ground $(1 \mathrm{~mm})$ and analyzed for DM $\left(105^{\circ} \mathrm{C}, 24 \mathrm{~h}\right)$. Ash was determined in a muffle furnace at $550^{\circ} \mathrm{C}$ for $8 \mathrm{~h}$. Organic matter was calculated 
Table 2. Effects of fumarate $(\mathrm{F} ; 0,5$, or $10 \mathrm{mM})$ on fermentation end-products during in vitro ruminal incubation $(6 \mathrm{~h})$ without or with ammonium bicarbonate $\left(\mathrm{NH}_{4} \mathrm{HCO}_{3}\right)$ as substrate $(\mathrm{S})$

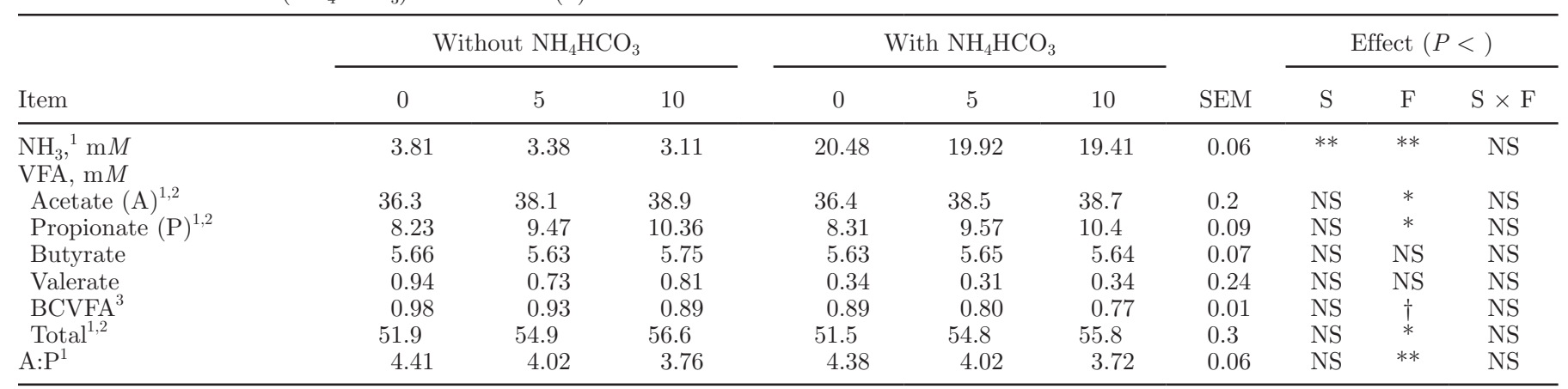

${ }^{1}$ Linear effect of added fumarate $(P<0.05)$.

${ }^{2}$ Quadratic effect of added fumarate $(P<0.05)$.

${ }^{3}$ Branched-chain VFA (isobutyrate + isovalerate).

$\dagger P<0.10 ;{ }^{*} P<0.05 ; * * P<0.01$.

by difference. Ether extract and $\mathrm{CP}$ were determined according to AOAC (1990). For soluble CP, feeds were immersed in distilled water at $39^{\circ} \mathrm{C}$ for $1 \mathrm{~h}$ before filtration through Whatman 54 filter paper (Whatman, Clifton, NJ). The residues on the paper were analyzed for $\mathrm{CP}$ and designated as insoluble CP. Soluble CP was estimated as difference between total $\mathrm{CP}$ and insoluble CP.

The NDF, ADF, and acid detergent lignin were analyzed by the method of Van Soest et al. (1991). Nonfiber carbohydrate content was calculated by subtracting $\mathrm{CP}$, ether extract, and NDF from OM. Hemicellulose (NDF - ADF) and cellulose (ADF - acid detergent lignin) were calculated by difference. Gross energy was determined using a Parr adiabatic bomb calorimeter (Parr Instrument Company Inc., Moline, IL).

Urine was collected into glass jars that were emptied daily. Fifty milliliters of $50 \% \mathrm{HCl}$ was placed in each urine collection jar at the beginning of each daily collection to prevent loss of ammonia. Daily urine volumes were measured and a 10\% aliquot taken and composited with previous aliquots for each goat. Urine samples were frozen $\left(-20^{\circ} \mathrm{C}\right)$ at the end of collection period. Urine was analyzed for $\mathrm{N}$ using the Kjeldahl method (AOAC, 1990). Nutrient digestibility and $\mathrm{N}$ retention were calculated by difference between intake and fecal output and difference between digested $\mathrm{N}$ and urinary $\mathrm{N}$ output, respectively.

On d 21, jugular blood samples were collected from each doe using heparinized syringes before and $3 \mathrm{~h}$ after the a.m. feeding. Plasma was prepared by centrifugation $\left(3,000 \times g, 20 \mathrm{~min}, 4^{\circ} \mathrm{C}\right)$ and frozen for later analysis. Plasma samples were analyzed for urea N (no. 535, Sigma) and glucose (no. 315, Sigma) by an automatic instrument (Merck Vitalab Selectra, Merck, Germany). Does were weighed at the start and the end of study to monitor live weight changes.

\section{Statistical Analysis}

Data were analyzed as a completely randomized design by ANOVA using the GLM procedure (SAS Institute, 1998). For the in vitro fermentation experiment, sources of variation included substrate, fumarate, and substrate $\times$ fumarate interaction. The residual error term was used to test the significance of sources of variation. Regression analyses were used to determine the significance of linear and quadratic effects of fumarate levels. For the animal metabolism study, fumarate treatment was the only source of variation. All data were expressed as least squares means. Treatment effect was determined by an $F$ ratio, with $P<0.05$ being considered significant unless otherwise indicated.

\section{RESULTS}

\section{In Vitro Rumen Microbial Fermentation}

Table 2 shows the effects of fumarate addition on in vitro rumen fermentation $(6 \mathrm{~h})$ characteristics without or with added $\mathrm{NH}_{4} \mathrm{HCO}_{3}$. More $(P<0.01)$ ammonia accumulated at the end of incubation when $\mathrm{NH}_{4} \mathrm{HCO}_{3}$ was included. Individual and total VFA concentrations and acetate:propionate ratio were not different without or with $\mathrm{NH}_{4} \mathrm{HCO}_{3}$ inclusion.

The final concentration of ammonia decreased $(P$ $<0.05)$ linearly as the concentration of fumarate increased. However, the addition of fumarate increased (quadratic, $P<0.05$ ) acetate and propionate concentrations. Because of these changes, total VFA concentration followed a similar pattern $(P<0.05)$ in response to an increasing level of fumarate. Concentration of branched-chain VFA (BCVFA) tended to be decreased $(P<0.10)$ with fumarate addition. No differences were found for other VFA. Adding fumarate linearly reduced $(P<0.05)$ acetate:propionate ratios. 
Table 3. Effects of fumarate (F; 0, 5, or $10 \mathrm{mM}$ ) on fermentation end-products during in vitro ruminal incubation $(6 \mathrm{~h})$ with casein amino acid or peptide as substrate $(\mathrm{S})$

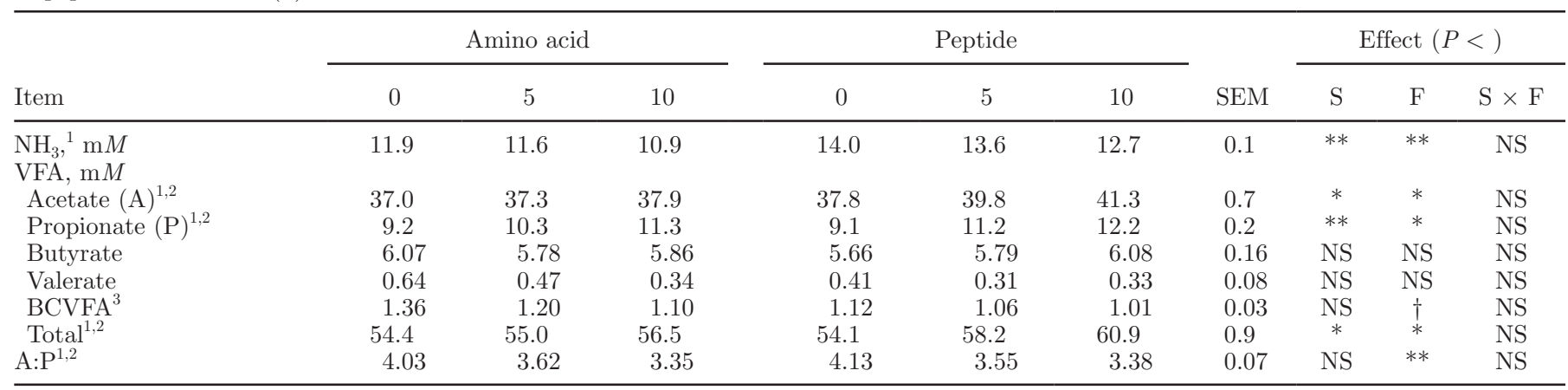

${ }^{1}$ Linear effect of added fumarate $(P<0.05)$.

${ }^{2}$ Quadratic effect of added fumarate $(P<0.05)$.

${ }^{3}$ Branched-chain VFA (isobutyrate + isovalerate).

$\dagger P<0.10 ;{ }^{*} P<0.05 ;{ }^{* *} P<0.01$.

The effects of fumarate on in vitro rumen fermentation $(6 \mathrm{~h})$ of amino acid and peptide sources are shown in Tables 3 and 4. Ammonia, and acetate, propionate, and total VFA concentrations were higher $(P<0.05)$ in incubations with the peptide compared with the amino acid source (Table 3). As shown in Table 4 for comparison between peptides, incubation with casein peptide resulted in greater $(P<0.05)$ ammonia, acetate, propionate, and total VFA concentrations than with gelatin peptide.

For amino acid and both peptide sources, adding fumarate linearly decreased $(P<0.05)$ ammonia concentration. However, the decrease in ammonia by fumarate addition was greater with casein peptide than with gelatin peptide (substrate $\times$ fumarate interaction, $P<0.05)$. Fumarate treatment increased $(P<0.05)$ acetate, propionate, and total VFA concentrations and decreased $(P<0.05)$ the acetate:propionate value quadratically. There was no treatment effect on the concentrations of butyrate and valerate, but addition of fumarate tended $(P<0.10)$ to decrease the concentration of BCVFA.

Table 5 shows the effects of fumarate on in vitro rumen fermentation $(24 \mathrm{~h})$ of hay and mixed diet. More $(P<0.05)$ ammonia accumulated with hay than with the mixed diet. As expected, concentrations of most individual and total VFA were higher $(P<0.05)$ and acetate:propionate ratio and $\mathrm{pH}$ value were lower $(P$ $<0.05)$ for the mixed diet than for hay. Digestibility of NDF and activities of endoglucanase and xylanase were greater $(P<0.05)$ when the mixed diet was used as substrate.

With both feed substrates, addition of fumarate linearly decreased $(P<0.05)$ ammonia concentration and acetate:propionate ratio. Adding increasing concentrations of fumarate quadratically increased $(P<$

Table 4. Effects of fumarate (F; 0, 5, or $10 \mathrm{mM})$ on fermentation end-products during in vitro ruminal incubation $(6 \mathrm{~h})$ with casein or gelatin peptide as substrate $(\mathrm{S})$

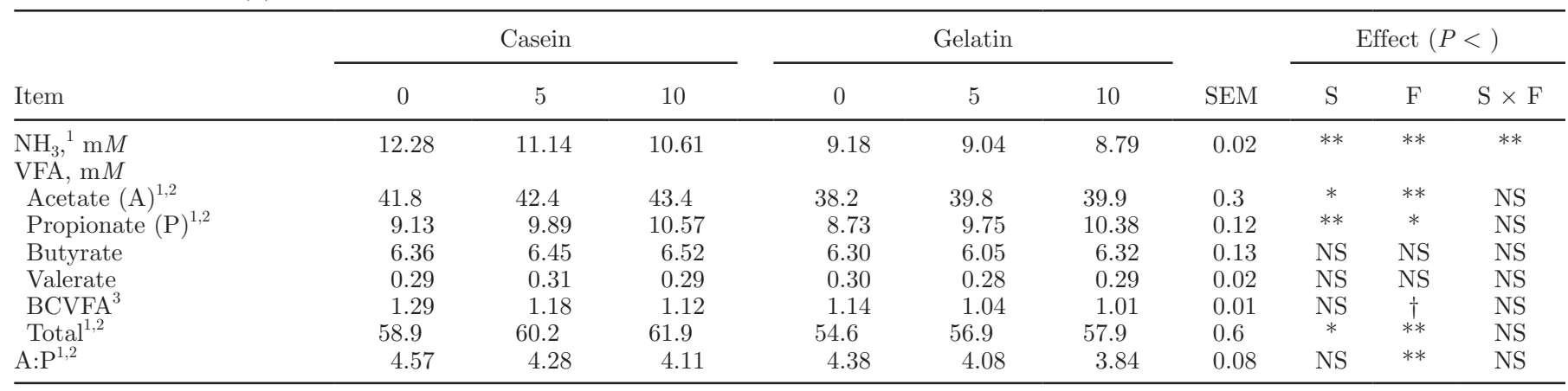

${ }^{1}$ Linear effect of added fumarate $(P<0.05)$.

${ }^{2}$ Quadratic effect of added fumarate $(P<0.05)$.

${ }^{3}$ Branched-chain VFA (isobutyrate + isovalerate).

$\dagger P<0.10 ;{ }^{*} P<0.05$; ** $P<0.01$. 
Table 5. Effects of fumarate (F; 0, 5, or $10 \mathrm{mM}$ ) on fermentation end-products, NDF digestion (\%), and endoglucanase and xylanase activities $(\mu \mathrm{mol} / \mathrm{mL}$ per $\mathrm{min})$ during in vitro ruminal incubation $(24 \mathrm{~h})$ with bermudagrass hay or mixed diet $(60 \%$ hay $+40 \%$ concentrate $)$ as substrate (S)

\begin{tabular}{|c|c|c|c|c|c|c|c|c|c|c|}
\hline \multirow[b]{2}{*}{ Item } & \multicolumn{3}{|c|}{ Bermudagrass } & \multicolumn{3}{|c|}{ Mixed diet } & \multirow[b]{2}{*}{ SEM } & \multicolumn{3}{|c|}{ Effect $(P<)$} \\
\hline & 0 & 5 & 10 & 0 & 5 & 10 & & $\mathrm{~S}$ & $\mathrm{~F}$ & $\mathrm{~S} \times \mathrm{F}$ \\
\hline $\mathrm{NH}_{3},{ }^{1} \mathrm{~m} M$ & 20.1 & 18.8 & 17.9 & 18.9 & 17.1 & 16.9 & 0.1 & $*$ & $*$ & NS \\
\hline \multicolumn{11}{|l|}{$\mathrm{VFA}, \mathrm{m} M$} \\
\hline Acetate $(\mathrm{A})^{1,2}$ & 58.1 & 58.4 & 58.5 & 66.3 & 71.6 & 72.4 & 0.4 & $* *$ & $* *$ & NS \\
\hline Propionate $(\mathrm{P})^{1,2}$ & 13.9 & 16.9 & 19.2 & 17.2 & 22.2 & 25.4 & 0.2 & $* *$ & $*$ & NS \\
\hline Butyrate $^{1,2}$ & 8.89 & 9.62 & 9.71 & 12.6 & 13.2 & 13.4 & 0.4 & $*$ & $*$ & NS \\
\hline Valerate & 0.72 & 0.91 & 0.76 & 0.93 & 1.01 & 1.06 & 0.08 & NS & NS & NS \\
\hline $\mathrm{BCVFA}^{3}$ & 1.44 & 1.41 & 1.34 & 1.88 & 1.74 & 1.62 & 0.03 & $*$ & $t$ & NS \\
\hline Total $^{1,2}$ & 83.0 & 87.2 & 89.5 & 98.9 & 109.8 & 113.9 & 1.7 & $*$ & $* *$ & NS \\
\hline $\mathrm{A}: \mathrm{P}^{1}$ & 4.19 & 3.46 & 3.01 & 3.86 & 3.23 & 2.86 & 0.05 & $* *$ & $* *$ & NS \\
\hline $\mathrm{pH}$ & 6.74 & 6.60 & 6.77 & 6.53 & 6.59 & 6.53 & 0.07 & $*$ & NS & NS \\
\hline NDF digestion & 29.6 & 30.8 & 31.6 & 36.2 & 37.1 & 39.2 & 0.5 & $*$ & $*$ & NS \\
\hline \multicolumn{11}{|l|}{ Activity } \\
\hline Endoglucanase $^{1}$ & 2.13 & 2.29 & 2.38 & 3.61 & 4.18 & 4.83 & 0.06 & $*$ & $* *$ & NS \\
\hline Xylanase $^{1}$ & 2.79 & 3.18 & 3.72 & 3.52 & 4.09 & 4.42 & 0.07 & $*$ & $* *$ & NS \\
\hline
\end{tabular}

${ }^{1}$ Linear effect of added fumarate $(P<0.05)$.

${ }^{2}$ Quadratic effect of added fumarate $(P<0.05)$.

${ }^{3}$ Branched-chain VFA (isobutyrate + isovalerate).

$\dagger P<0.10 ;{ }^{*} P<0.05$; ${ }^{* *} P<0.01$.

0.05) most individual and total VFA concentrations, but tended $(P<0.10)$ to decrease BCVFA. There was no effect of fumarate on valerate concentration or $\mathrm{pH}$. Fumarate addition increased $(P<0.05)$ NDF digestibility and endoglucanase and xylanase activities. No significant interactions between fumarate and feed were detected for any of the measured variables.

\section{Animal Intake, Nutrient Digestibility, and N Retention}

Table 6 presents ingredient and nutrient composition of ingested diets by dairy does with or without supplemental fumarate. Forage and concentrate pro- portions and chemical composition of ingested diets were unaffected by treatment.

The effects of feeding fumarate on weight change, feed intake, apparent whole-tract nutrient digestibility, $\mathrm{N}$ utilization, and plasma measurements are shown in Table 7. Weight change, and hay and total feed (hay plus concentrate) DMI were not influenced by adding fumarate to the diet. Dietary fumarate supplementation increased $(P<0.05)$ digestibility of gross energy $(\mathbf{G E}), \mathrm{CP}$, and cellulose. Digestibilities of DM, OM, NDF, ADF, and hemicellulose tended $(P$ $<0.10)$ to be greater for fumarate-fed does than for control does. No differences were detected in apparent

Table 6. Ingredient and nutrient composition of ingested diets by dairy does without (control) or with fumarate $(6 \mathrm{~g} /$ head per day) supplementation

\begin{tabular}{lcccc}
\hline Item & Control & Fumarate & SEM $^{1}$ & Effect $(P<)$ \\
\hline Ingredient & & & & \\
Hay, \% of DM & 62.7 & 61.4 & 2.6 & NS \\
Concentrate, \% of DM & 37.3 & 38.7 & 2.6 & NS \\
Nutrient & 4.39 & 4.48 & 0.03 & NS \\
Gross energy, Mcal/kg of DM & 89.2 & 89.1 & 0.3 & NS \\
OM, \% of DM & 9.63 & 9.71 & 0.32 & NS \\
CP, \% DM D & 2.04 & 2.03 & 0.05 & NS \\
Ether extract, \% of DM & 43.9 & 43.6 & 1.3 & NS \\
NDF, \% of DM & 19.3 & 19.0 & 0.6 & NS \\
ADF, \% of DM & 14.4 & 14.4 & 0.5 & NS \\
Cellulose, \% of DM & 4.45 & 4.39 & 0.16 & NS \\
Acid detergent lignin, \% of DM & 18.3 & 18.4 & 0.5 & NS \\
Hemicellulose, \% of DM & 33.7 & 33.8 & 1.3 & NS \\
NFC, \% of DM & & & \\
\hline
\end{tabular}

${ }^{1} \mathrm{n}=8$.

${ }^{2} \mathrm{OM}-\mathrm{CP}-$ ether extract $-\mathrm{NDF}$. 
Table 7. Body weight change, feed intake, apparent whole-tract nutrient digestibility, $\mathrm{N}$ utilization, and plasma measurements before $(0 \mathrm{~h})$ and after $(3 \mathrm{~h})$ feeding in dairy does without (control) or with fumarate $(6$ $\mathrm{g} /$ head per day) supplementation

\begin{tabular}{|c|c|c|c|c|}
\hline Item & Control & Fumarate & SEM & Effect $(P<)$ \\
\hline \multicolumn{4}{|l|}{ DMI, kg/d } & NS \\
\hline Hay & 0.40 & 0.38 & 0.05 & NS \\
\hline Total & 0.63 & 0.61 & 0.05 & NS \\
\hline \multicolumn{5}{|l|}{ Digestibility, \% } \\
\hline Gross energy & 63.4 & 66.8 & 0.7 & $*$ \\
\hline $\mathrm{DM}$ & 60.2 & 62.9 & 0.8 & $\dagger$ \\
\hline $\mathrm{OM}$ & 61.7 & 64.5 & 0.8 & $\dagger$ \\
\hline $\mathrm{CP}$ & 64.1 & 71.1 & 0.9 & $*$ \\
\hline Ether extract & 55.5 & 50.2 & 1.7 & NS \\
\hline $\mathrm{NDF}$ & 49.3 & 52.9 & 1.3 & $\dagger$ \\
\hline $\mathrm{ADF}$ & 37.8 & 42.6 & 1.5 & $\dagger$ \\
\hline Cellulose & 60.4 & 64.5 & 0.9 & $*$ \\
\hline Hemicellulose & 44.3 & 48.8 & 1.5 & $\dagger$ \\
\hline $\mathrm{NFC}^{1}$ & 90.8 & 90.7 & 1.1 & NS \\
\hline \multicolumn{5}{|c|}{$\mathrm{N}$ inputs and outputs, $\mathrm{g} / \mathrm{d}$} \\
\hline Intake $\mathrm{N}$ & 9.88 & 9.73 & 0.36 & NS \\
\hline Digested N & 6.31 & 6.91 & 0.11 & $*$ \\
\hline Fecal N & 3.57 & 2.83 & 0.37 & NS \\
\hline Urinary N & 3.02 & 2.86 & 0.11 & NS \\
\hline Retained N & 3.29 & 4.05 & 0.12 & NS \\
\hline \multicolumn{5}{|l|}{ Plasma } \\
\hline \multicolumn{5}{|l|}{ Urea $\mathrm{N}, \mathrm{mg} / \mathrm{dL}$} \\
\hline $0 \mathrm{~h}$ & 10.58 & 9.71 & 1.05 & NS \\
\hline $3 \mathrm{~h}$ & 11.3 & 10.8 & 1.1 & NS \\
\hline \multicolumn{5}{|l|}{ Glucose, mg/dL } \\
\hline $0 \mathrm{~h}$ & 54.7 & 64.5 & 1.6 & $* *$ \\
\hline $3 \mathrm{~h}$ & 59.3 & 67.3 & 1.7 & $*$ \\
\hline
\end{tabular}

${ }^{1} \mathrm{OM}-\mathrm{CP}-$ ether extract $-\mathrm{NDF}$.

$\dagger P<0.10 ;{ }^{*} P<0.05 ;{ }^{* *} P<0.01$.

digestibilities of ether extract and NFC by fumarate supplementation.

Intake, fecal, urinary, and retained $\mathrm{N}$ by goats were similar between treatments. However, daily digested $\mathrm{N}$ was increased $(P<0.05)$ with fumarate supplementation. Plasma urea $\mathrm{N}$ for does fed the control diet did not differ from that in does fed fumarate before and 3 $\mathrm{h}$ after the morning feeding. On the contrary, fumarate treatment increased $(P<0.05)$ plasma glucose at both sampling times.

\section{DISCUSSION}

\section{In Vitro Work}

Most research work with fumarate has been centered on ruminal methanogenesis and VFA profiles (GarcíaMartínez et al., 2005; Giraldo et al., 2007). Little research has been conducted specifically to investigate the effect of fumarate on ruminal ammonia accumulation. Ammonia is required by most rumen microbes (Allison, 1969). In particular, fiber-degrading ruminal bacteria primarily utilize ammonia as a source of $\mathrm{N}$ for growth (Bryant, 1973). Therefore, increasing ammonia availability for and utilization by microbes can enhance fiber digestion in the rumen (Van Soest, 1982).

In the present study, the level of ammonia N (5.3 $\mathrm{mg} / \mathrm{dL}$ ) in the control incubation without additional $\mathrm{NH}_{4} \mathrm{HCO}_{3}$ (Table 2) was close to the concentration, 4 to $6 \mathrm{mg} / \mathrm{dL}$, considered adequate for ruminal fiber digestion (Mackie and White, 1990). Addition of fumarate provided microorganisms with a key metabolic intermediate and decreased ammonia. When $\mathrm{NH}_{4} \mathrm{HCO}_{3}$ was added, ammonia availability was increased 5-fold, whereas fumarate decreased ammonia availability. No carbohydrates were provided during microbial incubations with $\mathrm{NH}_{4} \mathrm{HCO}_{3}$; therefore, it appears that fumarate was used by ruminal microbes to increase utilization of ammonia. Linehan et al. (1978) indicated that fumarate could serve as a carbon precursor for amino acid synthesis by incorporation of ammonia.

Peptides and amino acids are intermediates in ruminal protein degradation (Chen et al., 1987a). They are stimulatory for rumen microorganisms even when ammonia and fermentable carbohydrate are in excess (Cotta and Russell, 1982). Earlier studies (Chen et al., 1987b) indicated that peptides are the preferred substrates by ruminal microbes over the constituent 
amino acids in free form. Furthermore, peptides vary in resistance to ruminal degradation (Yang and Russell, 1992). When the supply of ruminally degradable carbohydrate is limited, large amounts of peptides and amino acids are deaminated and ammonia will accumulate in the rumen. Our results show that more ammonia accumulated with casein peptides than with amino acids. Moreover, a higher ammonia concentration was found during incubation with casein peptide than with gelatin peptide. These observations are consistent with results of previous work (Cotta and Russell, 1982).

Fumarate decreased ammonia and BCVFA concentrations simultaneously irrespective of the types of amino $\mathrm{N}$ incubated. These results indicate decreased deamination of amino acid and peptides by fumarate addition. When feed substrates were incubated with ruminal microorganisms, fumarate also decreased ammonia and BCVFA. It appears that in the presence of fermentable carbohydrate, fumarate may exert a similar effect. Bayaru et al. (2001) supplemented fumaric acid to cattle fed only roughage and found that both ruminal ammonia and BCVFA were decreased. Isobe and Shibata (1993) reported a reduction in ruminal BCVFA when fumarate was supplemented to goats. However, other in vitro (López et al., 1999; Giraldo et al., 2007) and in vivo (Beauchemin and McGinn, 2006) studies showed no effect of fumarate or fumaric acid on ruminal ammonia and BCVFA reduction. Lack of effects with fumarate could be caused by the use of high concentrate diets in their studies. When more readily fermentable carbohydrate is available for rumen microorganisms, ammonia utilization increases and amino acid deamination decreases. Therefore, fumarate addition would contribute little to the decrease in ammonia and BCVFA.

Fumarate can be converted into propionate and acetate following different pathways (Demeyer and Henderickx, 1967). In the present experiment, the addition of fumarate to various substrate incubations increased both acids. These increases contributed to the elevated total VFA with fumarate addition. The observed decrease in acetate:propionate ratio was consistent with previous observations in vitro (López et al., 1999; Giraldo et al., 2007) and in vivo (Isobe and Shibata, 1993; Bayaru et al., 2001; Beauchemin and McGinn, 2006), reflecting the fact that the extent of the increase in concentration by fumarate is greater for propionate than for acetate.

Earlier reports indicated that fumarate increased the rumen $\mathrm{pH}$ of concentrate fermentation in vitro (Carro and Ranilla, 2003) and in vivo (Mao et al., 2008). A dual mechanism of increased microbial lactate utilization (Nisbet and Martin, 1990) and $\mathrm{CO}_{2}$ production (López et al., 1999) by fumarate supplementation has been attributed to the increase in rumen $\mathrm{pH}$. In contrast, Bayaru et al. (2001) did not find any differences caused by the addition of fumaric acid in rumen $\mathrm{pH}$ in steers fed sorghum silage as the only feed. In the present study, no effect of fumarate on $\mathrm{pH}$ was expected because of the high forage substrate used, and no lactate was detected.

When hay or the mixed diet was incubated with ruminal microorganisms, ammonia was provided in excess of the amounts considered adequate for ruminal fiber breakdown (Mackie and White, 1990). The values of $\mathrm{pH}$ were within the range for optimal fiber digestion in the rumen (Mackie and White, 1990). Under these conditions, fumarate addition improved NDF digestion by ruminal microorganisms. A similar effect has been reported in vitro (López et al., 1999; Newbold et al., 2005) and in vivo (Isobe and Shibata, 1993). This effect would indicate a greater activity of fiber-degrading microorganisms in fumarate-added incubations, which is supported by the greater endoglucanase and xylanase activities. Other studies showed that fiber-degrading bacteria are enhanced by additional fumarate (Isobe and Shibata, 1993; Asanuma et al., 1999; López et al., 1999).

\section{Animal Study}

Fumarate can have beneficial influences on ruminal fermentation. However, little information is available to associate favorable rumen responses to fumarate supplementation with animal performance. Feed intake by does was not influenced by dietary fumarate treatment, as has been reported in previous studies with fumaric acid supplementation (1.1 to $2.9 \% \mathrm{DMI}$ ) to cattle (Bayaru et al., 2001; McGinn et al., 2004; Beauchemin and McGinn, 2006). In contrast, Wood et al. (2009) and Molano et al. (2008) found that supplementation of a high level of fumaric acid (up to $10 \%$ of diet) to lambs decreased feed intake. In the current study, fumarate supplied to does was consumed completely along with concentrate and represented approximately $1 \%$ of DMI. Ingested diet composition was unaffected by treatment, indicating no effect of fumarate on feed selection or sorting by does.

Does fed fumarate had increased whole-tract digestibility of GE and cellulose and tended to improve digestion of DM, NDF, ADF, and hemicellulose. The improved whole-tract fiber digestibility by fumarate is in accordance with the increased ruminal NDF digestion and fibrolytic activities observed during in vitro fermentation of the mixed diet, which is similar in forage:concentrate to diets consumed by does. Little has been done to investigate fumarate supplementation to dairy does and cows. In studies with beef cattle, Bayaru 
et al. (2001), McGinn et al. (2004), and Beauchemin and McGinn (2006) observed no effect of fumaric acid (1.1 to $2.9 \% \mathrm{DMI}$ ) on whole-tract digestion of DM, GE, NDF, and ADF. Digestibility of CP was improved by fumarate treatment, as has been reported by Bayaru et al. (2001) in Holstein steers fed only sorghum silage plus fumaric acid (2\% DMI). This finding implies that fumarate could improve feed protein utilization. Fumarate increased digested N, most likely because of improved $\mathrm{CP}$ digestibility because intake $\mathrm{N}$ did not alter. Similar to our observations, Stallcup and Barr (1983) reported no effect of fumaric acid $(60 \mathrm{~g} / \mathrm{d})$ on urinary $\mathrm{N}$ and $\mathrm{N}$ retention in Holstein bulls fed a high forage diet.

Bayaru et al. (2001) supplemented fumaric acid to steers fed forage alone and observed a postfeeding decrease in plasma urea $\mathrm{N}$ and an increase in glucose. We observed that fumarate decreased plasma urea $\mathrm{N}$ by $7 \%$, but the difference was not significant, similar to the result reported by Stallcup and Barr (1983). However, fumarate supplementation to does significantly increased pre- and postfeeding plasma glucose. In ruminants, a significant proportion of plasma glucose is produced by hepatic glucogenesis from propionate (Wiltrout and Satter, 1972). Increased plasma glucose concentration by fumarate supplementation in this study is supported by the elevated rumen propionate level observed in incubations using the mixed diet.

In conclusion, fumarate addition had significant effects on rumen microbial fermentation by decreasing ammonia accumulation and BCVFA and increasing acetate and propionate and NDF digestion. These effects were reflected in the improved whole-tract GE, CP, and cellulose digestion and increased plasma glucose concentration when dairy does were supplemented with fumarate.

\section{REFERENCES}

Allison, M. J. 1969. Biosynthesis of amino acids by ruminal microorganisms. J. Anim. Sci. 29:797-807.

Asanuma, N., M. Iwamoto, and T. Hino. 1999. Effect of the addition of fumarate on methane production by ruminal microorganisms in vitro. J. Dairy Sci. 82:780-787.

AOAC. 1990. Official Methods of Analysis. Vol. I. 15th ed. AOAC, Arlington, VA.

Bayaru, E., S. Kanda, T. Kamada, H. Itabashi, S. Andoh, T. Nishida, M. Ishida, T. Itoh, K. Nagara, and Y. Isobe. 2001. Effect of fumaric acid on methane production, rumen fermentation, and digestibility of cattle fed roughage alone. Anim. Sci. J. 72:139-146.

Beauchemin, K. A., and S. M. McGinn. 2006. Methane emissions from beef cattle: Effects of fumaric acid, essential oil, and canola oil. J. Anim. Sci. 84:1489-1496.

Bryant, M. P. 1973. Nutritional requirements of the predominant rumen cellulolytic bacteria. Fed. Proc. 32:1809-1813.

Carro, M. D., and M. J. Ranilla. 2003. Influence of different concentrations of disodium fumarate on methane production and fermentation of concentrate feeds by rumen microorganisms in vitro. Br. J. Nutr. 90:617-623.

Chaney, A. L., and E. P. Marbach. 1962. Modified reagents for determination of urea and ammonia. Clin. Chem. 8:130-132.

Chen, G., J. B. Russell, and C. J. Sniffen. 1987a. A procedure for measuring peptides in rumen fluid and data suggesting that peptide uptake is the rate-limiting step in ruminal protein degradation. J. Dairy Sci. 70:1211-1219.

Chen, G., H. J. Strobel, J. B. Russell, and C. J. Sniffen. 1987b. The effect of hydrophobicity on the uptake and deamination of peptides by ruminal bacteria in vitro. Appl. Environ. Microbiol. 53:2021-2025.

Cotta, M. A., and J. B. Russell. 1982. Effect of peptides and amino acids on efficiency of rumen bacterial protein synthesis in continuous culture. J. Dairy Sci. 67:226-234.

Demeyer, D. I., and M. K. Henderickx. 1967. Competitive inhibition of in vitro methane production by mixed rumen bacteria. Arch. Int. Physiol. Biochim. 75:157-159.

García-Martínez, R., M. J. Ranilla, M. L. Tejido, and M. D. Carro. 2005. Effects of disodium fumarate on in vitro rumen microbial growth, methane production and fermentation of diets differing in their forage:concentrate ratio. Br. J. Nutr. 94:71-77.

Giraldo, L. A., M. J. Ranilla, M. L. Tejido, and M. D. Carro. 2007. Influence of exogenous fibrolytic enzymes and fumarate on methane production, microbial growth and fermentation in Rusitec fermenters. Br. J. Nutr. 98:753-761.

Goering, H. K., and P. J. Van Soest. 1970. Forage Fiber Analyses (Apparatus, Reagents, Procedures and Some Applications). Agric. Handbook No. 379. ARS-USDA, Washington, DC

Isobe, Y., and F. Shibata. 1993. Rumen fermentation in goats administered fumaric acid. Anim. Sci. Technol. 64:1024-1030.

Linehan, B., C. C. Scheifinger, and M. J. Wolin. 1978. Nutritional requirements of Selenomonas ruminantium for growth on lactate, glycerol, or glucose. Appl. Environ. Microbiol. 35:317-322.

López, S., C. Valdés, C. J. Newbold, and R. J. Wallace. 1999. Influence of sodium fumarate on rumen fermentation in vitro. Br. J. Nutr. 81:59-64

Mackie, R. I., and B. A. White. 1990. Recent advances in rumen microbial ecology and metabolism: Potential impact on nutrient output. J. Dairy Sci. 73:2971-2995.

Mao, S. Y., G. Zhang, and W. Y. Zhu. 2008. Effect of disodium fumarate on ruminal metabolism and rumen bacterial communities as revealed by denaturing gradient gel electrophoresis analysis of 16S ribosomal DNA. Anim. Feed Sci. Technol. 140:293-306.

McDougall, E. I. 1948. Studies on ruminant saliva. I. The composition and output of sheeps saliva. Biochem. J. 41:99-104.

McGinn, S. M., K. A. Beauchemin, T. Coates, and D. Colombatto. 2004. Methane emissions from beef cattle: Effects of monensin, sunflower oil, enzymes, yeast, and fumaric acid. J. Anim. Sci. 82:3346-3356

Miller, G. L. 1959. Use of dinitrosalicylic acid reagent for determination of reducing sugar. Anal. Chem. 31:426-428.

Molano, G., T. W. Knight, and H. Clark. 2008. Fumaric acid supplements have no effect on methane emissions per unit of feed intake in wether lambs. Aust. J. Exp. Agric. Sci. 48:165-168.

Morgavi, D. P., C. J. Newbold, D. E. Beever, and R. J. Wallace. 2000. Stability and stabilization of potential feed additive enzymes in rumen fluid. Enzyme Microb. Technol. 26:171-177.

Newbold, C. J., S. López, N. Nelson, J. O. Ouda, R. J. Wallace, and A. R. Moss. 2005. Propionate precursors and other metabolic intermediates as possible alternative electron acceptors to methanogenesis in ruminal fermentation in vitro. Br. J. Nutr. 94:27-35.

Nisbet, D. J., and S. A. Martin. 1990. Effect of dicarboxylic acids and Aspergillus oryzae fermentation extract on lactate uptake by the ruminal bacterium Selenomonas ruminantium. Appl. Environ. Microbiol. 26:133-136.

Nocek, J. E., and J. B. Russell. 1988. Protein and energy as an integrated system. Relationship of ruminal protein and carbohydrate 
availability to microbial synthesis and milk production. J. Dairy Sci. 71:2070-2107.

NRC. 1981. Nutrient Requirements of Goats: Angora, Dairy, and Meat Goats in Temperate and Tropical Countries. National Academy Press, Washington, DC.

SAS Institute. 1998. SAS User's Guide: Statistics. Version 7 ed. SAS Inst. Inc., Cary, NC.

Stallcup, O. T., and J. T. Barr. 1983. Organic acid additions to ureacontaining diets and nitrogen metabolism and energy digestibility in cattle. Nutr. Rep. Int. 28:1061-1071.

Van Soest, P. J. 1982. Rumen microbes. Pages 152-177 in Nutritional Ecology of the Ruminant. O \& B Books Inc., Corvallis, OR.

Van Soest, P. J., J. B. Robertson, and B. A. Lewis. 1991. Methods for dietary fiber, neutral detergent fiber, and nonstarch polysaccharides in relation to animal nutrition. J. Dairy Sci. 74:3583-3597.

Wiltrout, D. W., and L. D. Satter. 1972. Contribution of propionate to glucose synthesis in lactating and nonlactating cows. J. Dairy Sci. $55: 307-317$.
Wood, T. A., R. J. Wallace, A. Rowe, J. Price, D. R. Yáñez-Ruiz, P. Murray, and C. J. Newbold. 2009. Encapsulated fumaric acid as a feed ingredient to decrease ruminal methane emissions. Anim. Feed Sci. Technol. 152:62-71.

Yang, C.-M. J., C.-T. Chang, S.-C. Huang, and T. Chang. 2003. Effect of lasalocid on growth, blood gases, and nutrient utilization in dairy goats fed a high forage-low protein diet. J. Dairy Sci. 86:3967-3971.

Yang, C.-M. J., and J. B. Russell. 1992. Resistance of proline-containing peptides to ruminal degradation in vitro. Appl. Environ. Microbiol. 58:3954-3958.

Yang, C.-M. J., and G. A. Varga. 1989. Effect of sampling site on protozoa, and fermentation end products in the rumen of dairy cows. J. Dairy Sci. 72:1492-1498. 